\title{
Crisis Management: Innovative Financial and Accounting Technologies
}

\author{
Natalia Iershova ${ }^{1}$, Oksana Portna ${ }^{2}$, Viktoriia Tretyak ${ }^{2}$, \\ Karina Moskalenko ${ }^{2}$, Oleksii Vasyliev ${ }^{2}$ \\ ${ }^{1}$ National Technical University "Kharkiv Polytechnical Institute”, 2 Kirpichov St., Kharkiv, Ukraine \\ ${ }^{2}$ V.N. Karazin Kharkiv National University, 4 Svobody Sq., Kharkiv, Ukraine
}

\begin{abstract}
Under crisis conditions, the behavioural model for business entities is determined by the effectiveness of crisis management which requires the use of innovative financial and accounting technologies, as well as changes that occur within the overall management system of the company. In the course of the current research the mechanism of crisis management of business activity and its elements is proposed and the system of procedural support for the crisis management process is determined. The compliance of accounting and financial instruments and technologies with the functions of crisis management of the company is presented. The paper analyses the importance of organizational changes in the process of crisis management. This allows optimizing the processes of information support for the decision-making process and improving the quality of crisis management of a company.
\end{abstract}

Keywords - Crisis management, innovative accounting technologies, financial instruments, resistance to change, competencies.

DOI: 10.18421/TEM102-34

https://doi.org/10.18421/TEM102-34

Corresponding author: Oksana Portna, V.N. Karazin Kharkiv National University, Kharkiv, Ukraine. Email: o.v.portna@gmail.com

Received: 21 December 2020.

Revised: 30 March 2021.

Accepted: 05 April 2021.

Published: 27 May 2021.

(cc)BY-NC-ND 2021 Natalia lershova et al; published by UIKTEN. This work is licensed under the Creative Commons Attribution-NonCommercial-NoDerivs 4.0 License.

The article is published with Open Access at www.temjournal.com

\section{Introduction}

The imperative of the company's performance in a market economy is its flexibility in the business environment, constant search and adjustment of business strategies. Crises in the global economy are having an increasing impact on corporate governance methodology. The current study in the field of crisis management focuses mainly on approaches to developing a strategy that is modulated according to the risks that arise in the process of its implementation [1], [2]. In this aspect, the issues of ensuring the implementation of the strategic program of the company become important. Horvathova J. \& Mokrisova M. emphasize the importance of financial stability in ensuring business efficiency [3]. In our opinion, financial stability is the result of crisis actions. We support Handayani B. D. et al. [4], who proved that the effectiveness of the corporate governance mechanism provides high financial results by ensuring the growth of corporate value. Wyrwa, J. notes that one of the most important modern challenges for businesses in the context of Industry 4.0 is to find sources of funding for providing management support [5]. When studying the problem of company management based on a crisis approach, many scholars note the important role of relevant information in making management decisions. Thus, Shevchenko L. et al. [6] studied the methodological issues of accounting and analytical support for the resource potential of enterprises to create integrated information systems. Bondar M. et al. [7] justify the importance of information management reporting for decision-making to ensure the business success.

Implementation of crisis management involves changes in the operating environment of the company. Such changes are diverse, complex, interconnected and require the use of innovative tools and technologies to generate the information that will be useful for management. According to the study carried out by the Association of Managers, the main problems faced by companies when implementing management innovation are insufficient communication and coordination between departments, lack of a common vision of the possible results obtained due to such innovations, a common strategy for their implementation as well as employees' resistance to the introduction of management innovation (Fig. 1). 


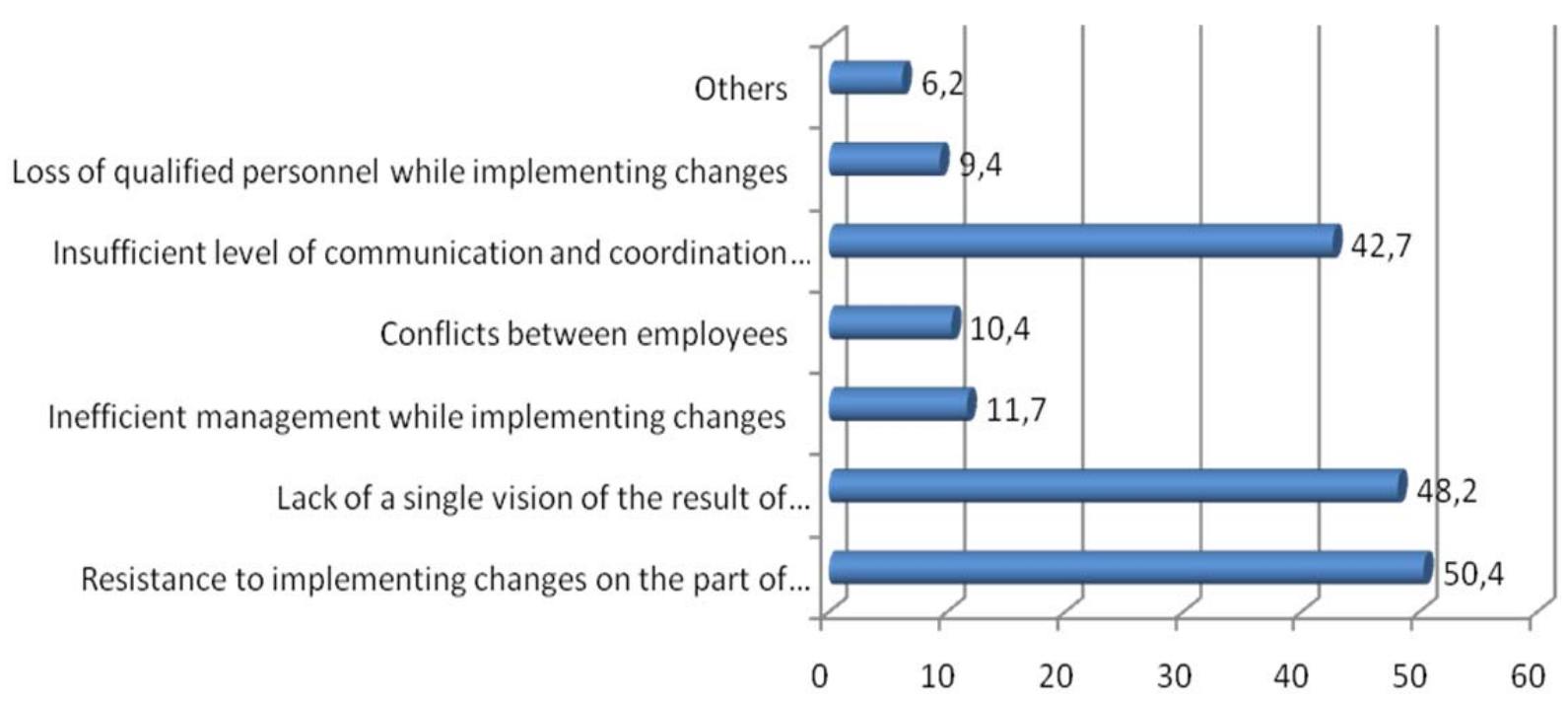

Figure 1. Main problems faced by companies in implementing crisis measures*

* adapted [8]

Active scientific and practical researches show that the problem of resistance to change is the one that turns out to be crucial for companies today [9], [10]. We agree with the conclusions made by Atamas P. et al. [11], who proved that the changes concern, first of all, the setting of goals by economic entities, determining the relationship between personal goals of business owners and social interests, as well as taking into account all stakeholders. According to Renkema et al. [12] the strength of resistance to change depends on the degree of employees' awareness of the business strategy, need for change and vision of their role as participants in providing changes and their place in the future organization.

According to Neyden et al. [13], staff resistance to crisis measures may be due to such reasons as unwillingness to do extra work, feeling of instability and insecurity, low level of readiness for change, the belief that change will not improve anything, and others. Therefore, according to Ijaz \& Vitalis [14], overcoming resistance should begin with identifying the reasons due to individual attitudes and attitudes to change. To overcome or minimize resistance to change associated with the implementation of innovations in the company, it is advisable to use certain methods proposed by Gruman \& Saks [15]. An analysis of the factors affecting "resistance to change" in personnel and empirical results help us understand the patterns of the organizational change process when implementing crisis management measures in the company's activities.

Internal information helps managers and professionals to develop and implement management decisions; however, there is usually a need for methods to collect, group, aggregate and store it. In support of this thesis, Kożuch A. [16] emphasizes the necessity to solve the issue of introducing innovative accounting technologies since, according to Kożuch
A. [16], technologies, calculation methods and accounting requirements do not fulfil their main role for management. Shamsi S. Bawaneh [17], Koev S. R. et al. [18] suggest justifying management decisions by using a balanced scorecard that includes a resource component which provides one of the information sources to identify "bottlenecks" when implementing crisis measures.

Innovative accounting technologies as an information platform for crisis decision-making are studied in many research works [17]. Scientists have identified and proven that information generation technologies determine positive changes in the management system (they are embodied in a set of interconnected processes in response to the implementation of a crisis management system).

\section{Research Method}

To implement crisis management as a subsystem in the overall management system of a company, a mechanism has been developed and proposed to ensure its functioning. A block diagram of crisis management as a subsystem (supersystem) of the general management system of the enterprise is shown in Fig. 2.

The core of crisis management of the company is a mechanism. The mechanism of crisis management consists of substantive and functional elements, subjects and objects.

Substantive elements are determined by the values, norms, rules, principles of crisis management, relations and connections between participants in the crisis process, and the regulatory framework of crisis management. The substantive block comprises the "body" of crisis management of a company, its substantive basis. 


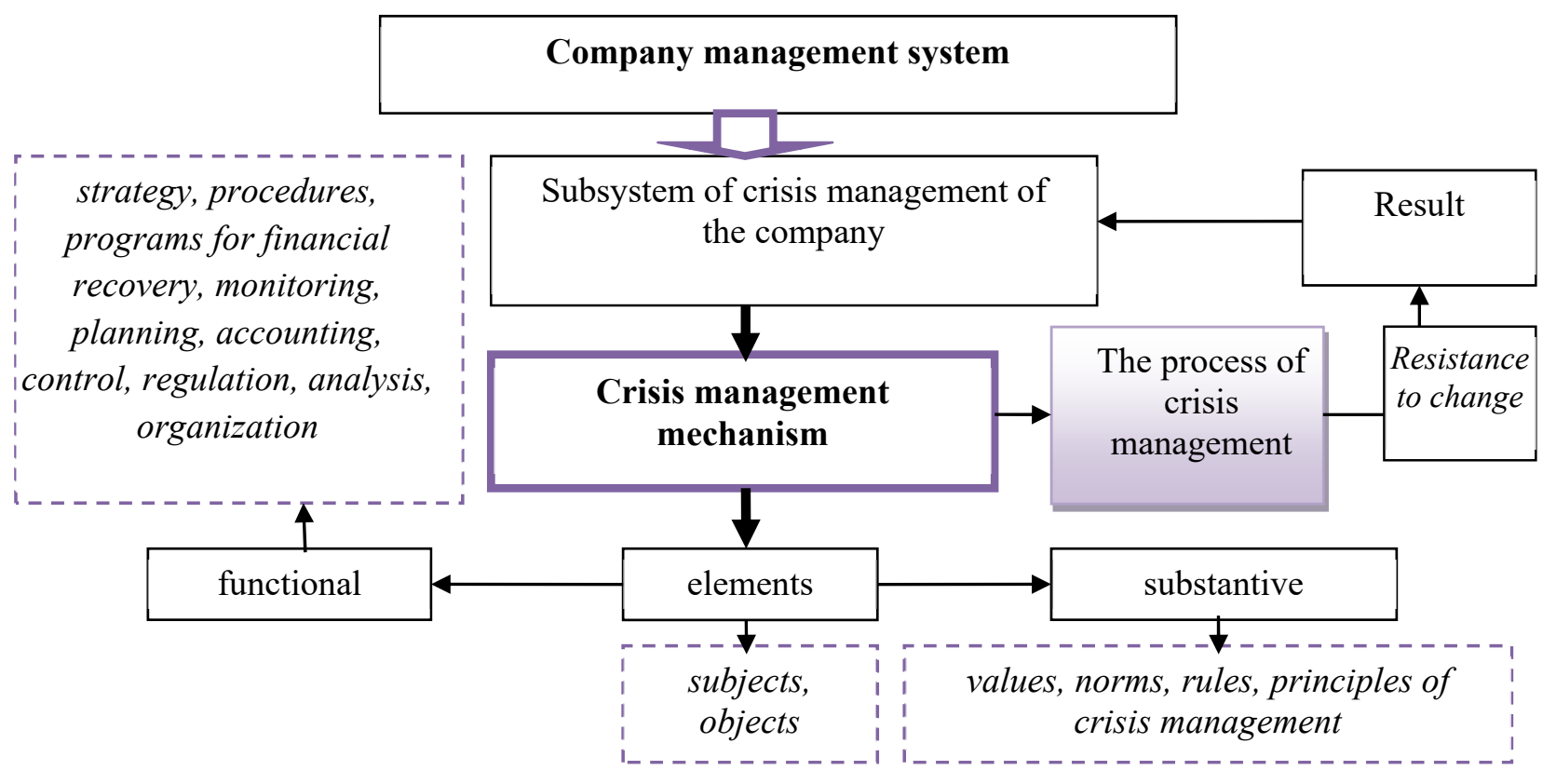

Figure 2. The mechanism of business crisis management*

* Source: own development of the authors.

Functional elements that constitute the crisis management mechanism are as follows: strategy, policy, crisis procedures, and programs for financial recovery, monitoring, coordination and organization of their implementation, introduction of incentives, accounting and control of the results of crisis management.

The subject of business crisis management is a group of persons who provide the operation of the crisis management object by applying various techniques and methods of management activities. They are top managers, crisis managers, a collegial group of various specialists in related fields (economist, production manager, personnel specialists, financial manager, crisis accountantanalyst) and company owners.

The objects of business crisis management are activities (operational, investment, innovation, financial), resources (staff, assets, finance, and capital), organizational structure and culture.

The peculiarity of crisis management for the company lies in the increased complexity of management processes. Therefore, the level of requirements for those who make the most important, strategic decisions is growing.

Based on the definitions provided by Tomsen [10], Van der Wal, Huberts [20], organizational values are standards that have a certain weight which is given to alternative goals when making decisions. Most often, organizational values are classified into values-goals (terminal values) and values-means (operational, instrumental) [21].

Norms and rules relate to legislative, corporate regulation of crisis management measures in the company.

Principles of crisis management are as follows:

- consistency, which provides a coordinated approach to crisis measures;

- alternativeness, which provides the development of several options for anti-crisis measures with the ability to choose the best and most effective of them;

- complexity, which provides a comprehensive approach to resolving the crisis;

- "bottleneck" or "critical resources" for their diagnosis and expansion.

- priority, which ensures the implementation of the general program and the subordination of operational plans to it;

- iterativeness, which provides a constant analysis of the crisis cycle and a step-by-step approach to strategy development.

Separately, the process of business crisis management deserves consideration, which is provided by the following elements: organizational, accounting and analytical, financial (Figure 3 ). 


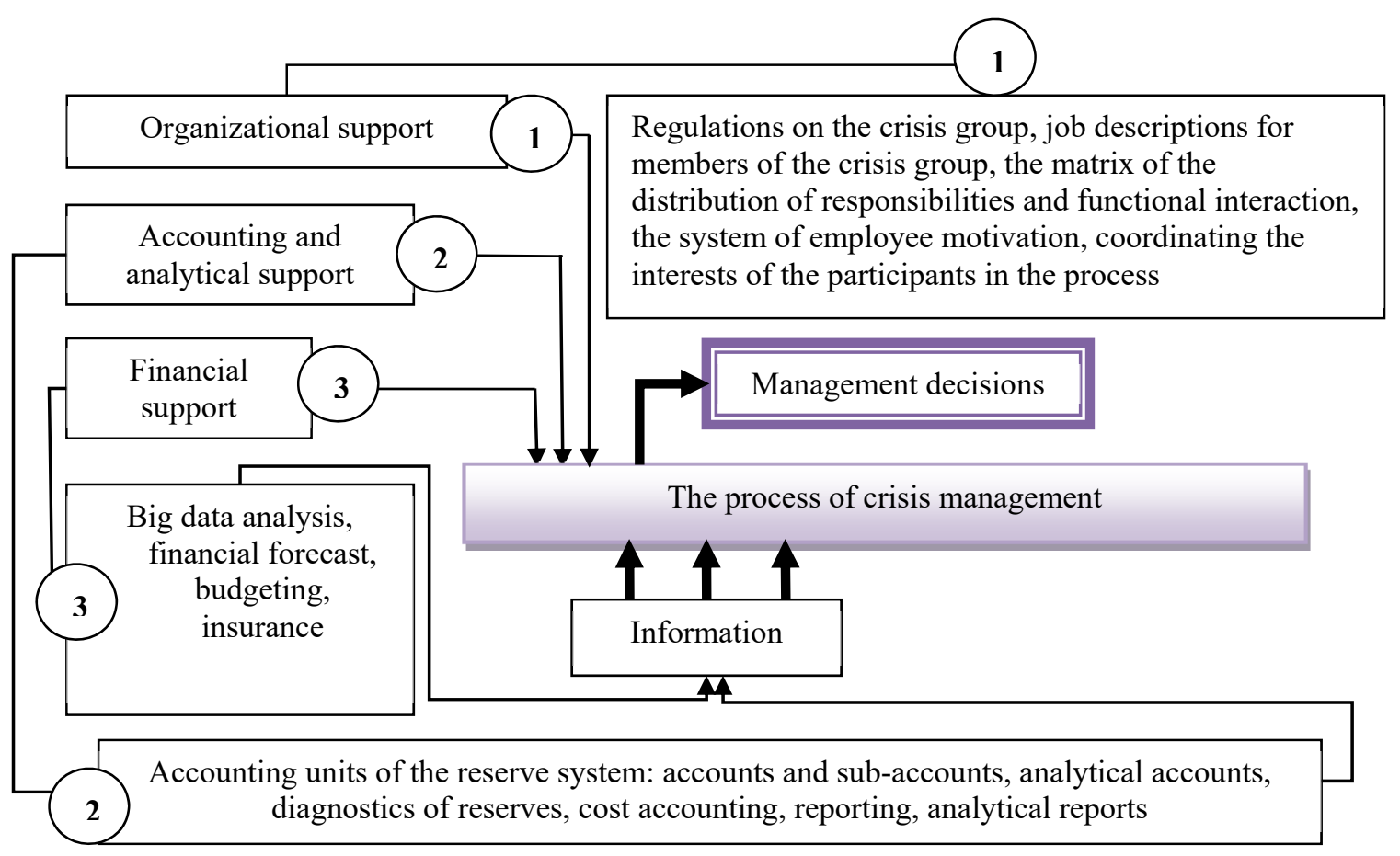

Figure 3. The system of procedural support for the process of business crisis management*

*Source: own development of the authors.

Accounting technologies for crisis management is a set of economic tools and methods of collecting, grouping, systematizing, processing information of financial and non-financial nature [7]. Such technologies in our opinion can be: accounting units of the reserve system: accounts and sub-accounts, analytical accounts, etc. Management accounting technologies for crisis management are more flexible and manoeuvrable in order to generate the necessary information in the process of organizational change. This is due to the freedom from regulatory influence and the optional use of certain methodological techniques that are inherent in financial accounting. Accounting technologies for the purposes of crisis management are aimed, inter alia, at forming management reports, analytical notes, databases, where the information about the basic parameters of the external and internal environment of the company is equally generated with respect to the same degree of aggregation. In a state of crisis, the following key technologies of management accounting become relevant: the concept of lean production, "Just-intime" management, a system of balanced and efficiency indicators, $\mathrm{ABC}$ analysis of suppliers and buyers, activity-based costing, and a value chain analysis. Analytical tools are becoming important to support the management decision-making process: SWOT analysis, STEP analysis, PIMS analysis, etc. [17], [19].

Correspondence of tools and technologies to the functions of accounting and financial support is given in Table 1.

Table 1. Compliance of tools and technologies with the functions of accounting and financial support of business crisis management*

\begin{tabular}{|l|l|}
\hline \multicolumn{1}{|c|}{ Accounting support functions } & \multicolumn{1}{c|}{ Innovative accounting instruments and technologies } \\
\hline $\begin{array}{l}\text { Accounting for causal relationship } \\
\text { between the unstable financial } \\
\text { condition and business processes }\end{array}$ & $\begin{array}{l}\text { Accounting units of the reserve system: accounts and sub-accounts, analytical } \\
\text { accounts, reserve diagnostics, cost accounting by types of activities and cost } \\
\text { centres, CVP analysis, inventory, plan-fact analysis, accounting policy, } \\
\text { problem-oriented maps }\end{array}$ \\
\hline $\begin{array}{l}\text { Standardization and regulation of } \\
\text { accounting procedures }\end{array}$ & $\begin{array}{l}\text { Standard "Information Support for Crisis Management", job descriptions for } \\
\text { crisis accountants-analysts }\end{array}$ \\
\hline $\begin{array}{l}\text { Prompt methodological support for } \\
\text { decision-making }\end{array}$ & $\begin{array}{l}\text { Break-even analysis, grouping, systematization of data and information, system } \\
\text { of internal management reporting }\end{array}$ \\
\hline \multicolumn{1}{|c|}{ Financial support functions } & \multicolumn{1}{|c|}{ Innovative financial instruments and technologies } \\
\hline Environmental monitoring & Static and dynamic model of macroeconomic and microeconomic parameters \\
\hline $\begin{array}{l}\text { Prompt methodological support for } \\
\text { decision-making }\end{array}$ & $\begin{array}{l}\text { General and consolidated budgets, control over compliance with the law, } \\
\text { analysis of deviations, analysis of cash flows }\end{array}$ \\
\hline
\end{tabular}

*Source: own development of the authors. 
The use of such accounting technologies is ensured by the qualification of the accounting specialist, his initiative and competence of professional judgements. As a result, the necessary accounting and analytical information is formed for crisis management decisions by the company's management.

Financial technologies and tools are more related to the function of ensuring the implementation of crisis measures. Analytical and planning tools are relevant for: big data analytics, financial forecast, budgeting, hedging, insurance, etc.

The adoption of crisis management decisions by the company's management and their implementation by the staff certainly depends on changes in the company and measures to overcome them, some of which are: their development results from the competence of the company's top management; the presence of a well-established system of management communications, and effectiveness of feedback. The level of business ethics and tolerance for possible violations of compliance policy (level of risk appetite) are also important.

The distribution of powers and responsibilities for decision-making, counteracting the opportunistic behaviour of employees in connection with changes in the organizational structure of enterprise management is a necessary and important element of crisis management. The functioning of crisis management at the enterprise involves changes in the management system of the company and the management of these changes. The level of change in the enterprise is determined by the level of crisis or risk. Thus, as the level of crisis or risk increases, the need for change increases as well (Figure 4).

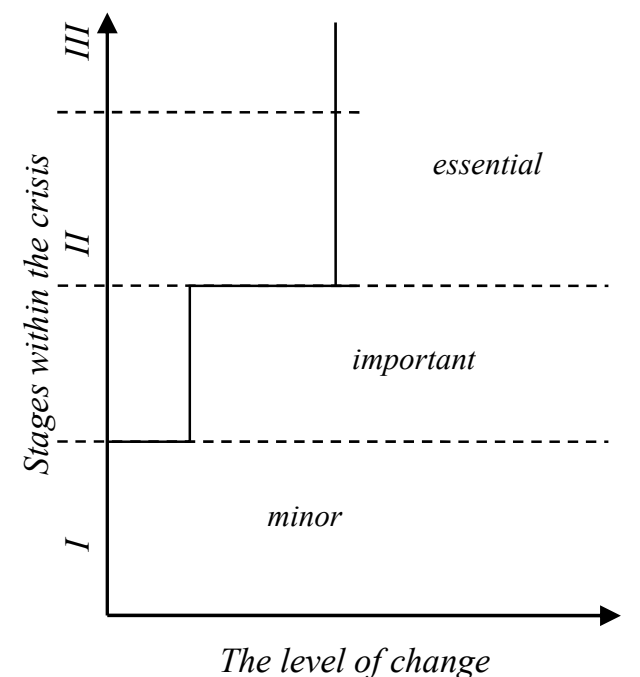

Figure 4. Organizational change in the company depending on the stage within the crisis according to Kristek
Stages within the crisis: I - potential crisis; II latent (open) crisis; Stage III — an acute crisis that can be overcome; Stage IV - an acute insurmountable crisis. As the crisis deepens, resistance to change increases while the change accompanies the crisis management process, especially if the company has poor management processes. Insufficient control function or its absolute absence may slow down the process of implementing crisis management decisions and in some cases lead to completely opposite results due to strong resistance displayed by employees and company departments. The ability of executives and managers to prevent the effects of the crisis is limited by the impact of problems in the social sphere. As the business environment moves faster, crisis actions become of greater importance, companies need to review established processes and manage change through mindset. Changes is a very important process for the organization since it allows adapting to everchanging external and internal environments, as well as learn new techniques and knowledge to achieve better results. Therefore, the emotional and behavioural aspects of organizational change in the course of modifying the company's management system have to be taken into account. Maintaining an effective team during a crisis is the most important strategic advantage that is possible through a system of motivation, as well as a change in approaches to the performance of functional tasks by employees in accordance with job descriptions.

Changes in the process of crisis management should take place in two directions, i.e. personal changes and organizational changes. When providing crisis measures in the company, organizational change in the management system of its activity is seen by some employees as a change in their tasks, responsibilities and subordination, change in the nature and order of performance of functional duties (additions or dismissals). Such change is determined by job descriptions for the staff. In order to analyze and describe the change, it is necessary to review the structure and ratio of the components that constitute the company's management system, which are often considered from the standpoint of a functional approach.

\section{Results}

To generalize the sequence of actions for the implementation of crisis management in the company's activities, it is advisable to use a model filled with specific content (Fig. 5). 


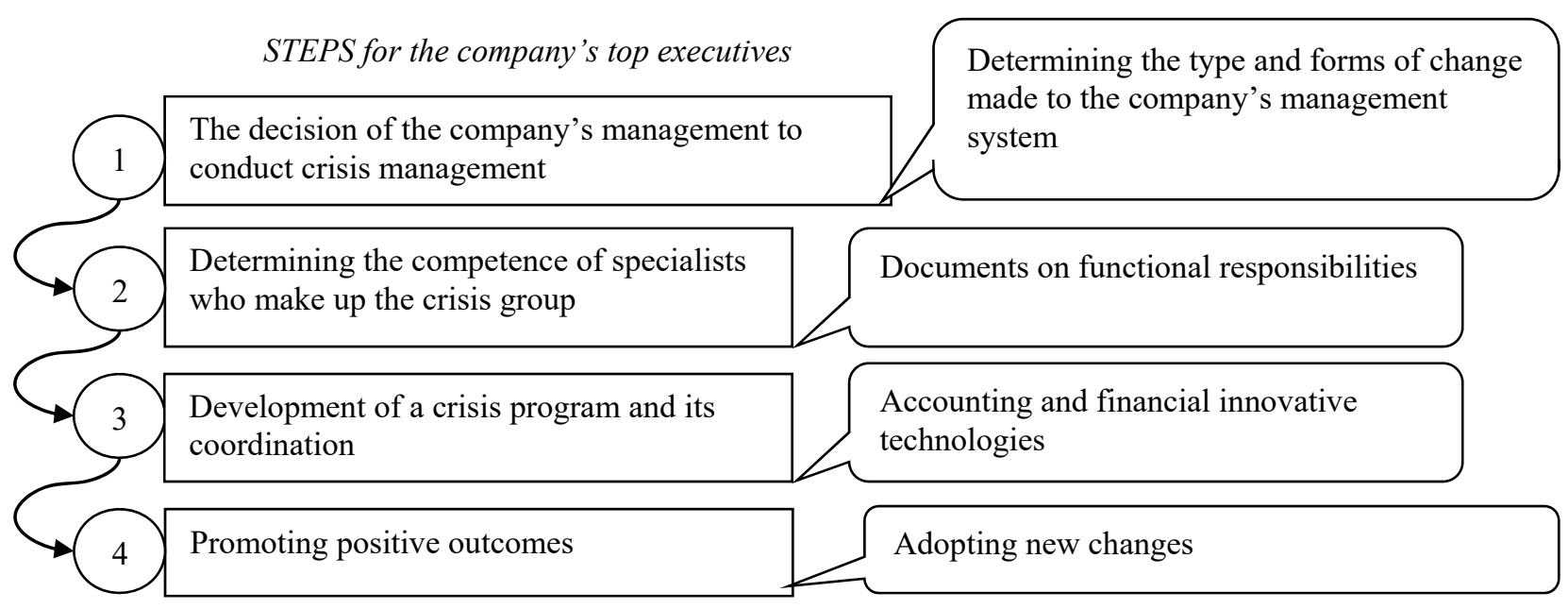

Figure 5. Model of crisis management changes in the company's management system*

*Source: own development of the authors.

Step 1. When deciding on the necessity to implement measures for crisis management, top executives (owners) of the company rely on the results obtained from diagnostics, namely steady dynamics of deterioration observed in the overall achievement of the company. This step determines the type and forms of change that top executives (owners) consider necessary to implement in the management system of the company. Change in the overall management system is aimed, inter alia, at strengthening integration processes. This will allow using more fully and accurately the potential of the competencies of professionals who are included in the group. Besides, at this step it is advisable to analyze and evaluate the effectiveness of the company's top management. What can be done by the method of quantitative and qualitative assessment of the functional components of management systems based on the method of expert assessments is shown in Figure 6.

\begin{tabular}{c|l|}
\cline { 2 - 2 } $\begin{array}{c}\text { Management } \\
\text { efficiency, ME }\end{array}$ & 01 Finance \\
\cline { 2 - 2 } & 02 Production \\
\cline { 2 - 2 } & 03 Economics \\
\hline & 04 Marketing \\
\hline & 05 Accounting \\
\hline & 06 Staff \\
\hline
\end{tabular}

Figure 6. Tree for evaluating the effectiveness of managerial processes within a company*

*Source: own development of the authors.

$$
\mathrm{ME}=\Sigma \mathrm{K}_{\mathrm{ij}} / \mathrm{n}
$$

Within this equation, $K_{i j}-$ evaluation of the effectiveness of management functions; $i$ - functions defined by the $j_{-t h}$ expert; $n$ - number of experts.

This model can be used to monitor the current state of efficiency with respect to the company's management system of the company as a whole and its departments, structural units. It also allows diagnosing the dynamics of these parameters.

Step 2. The introduction of crisis management requires creating a crisis group, which is enshrined in the Regulations on the crisis group. Job descriptions for members of the crisis group are developed and approved in accordance with the procedure adopted by the company. A matrix of responsibility distribution and functional interaction and information flow schemes are built, a motivation system for group employees is developed and approved.

Step 3. A crisis program is developed. Innovative accounting and financial technologies are used for this purpose. The core of the crisis program is risk management. Risks are identified through the use of monitoring technology. Monitoring of the internal environment allows determining the structure of resource potential; the level of security, intensity and efficiency of material, labour, financial and information resources, etc. Monitoring the external environment makes it possible to gain awareness of the external aspects of the enterprise and the state of the competitive environment. A large variety of management accounting tools are often used in conjunction with advanced technologies in management, which expands the range of competencies of the accounting officer (Figure 7). 


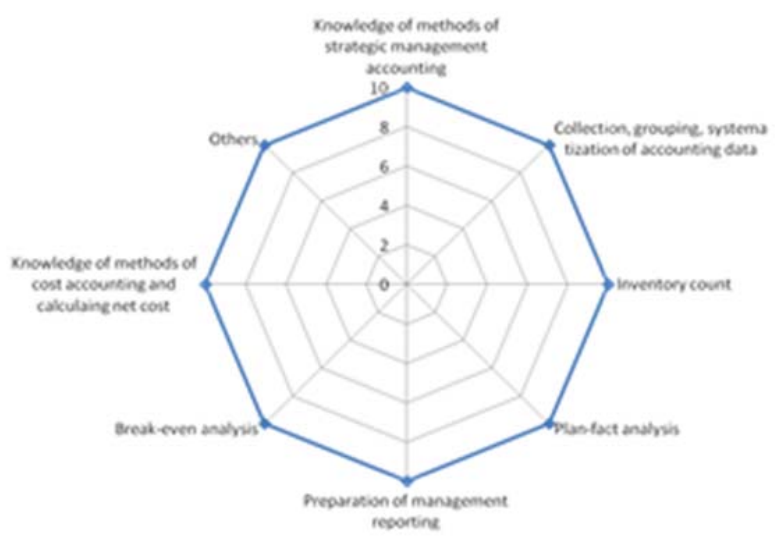

Figure 7. Competence map of crisis accountant-analyst*

*Source: own development of the authors.

Step 4 - Promoting positive outcomes. The head of the crisis team (crisis manager), who works on setting goals and expected results, should maintain feedback, provide instruction and training, analyse the achievements and provide incentives for employees. In order to accept new change, the crisis manager must make professional efforts to streamline the procedures for performing the functions of each employee, to unite in a single issue of crisis management and operational work at the level of a particular executor.

These goals come from the crisis program. In other words, the promotion of positive results involves establishing a liaison between strategies, individual goals and performance criteria at all levels of the management hierarchy. In order to assess the system of management communication and the effectiveness of feedback, the methods of expert survey (questionnaire, survey, interviewing) are effective. When introducing crisis management in the company, there are following determinants of manager' attention:

- activating talented employees;

- setting an attractive goal;

- selecting creative and innovative management tools;

- defining realistic but tight terms;

- providing available resources and support.

Active management measures to overcome resistance to change on the part of staff:

- Motivators applied to the personnel when implementing crisis management in the company: information; building corporate traditions; professional development; feedback; positive environment and attitudes;
- Consistency in providing additional education: certification training; retraining; seminars; forums; practical conferences, etc.;

- Continuous on-the-job training: study of special literature; consultations.

The practical implementation of results obtained from the current study was carried out on the example of agriculture companies. The sample of respondents comprised 330 employees from 18 companies in Ukraine, whose field of professional activity is agriculture. This area of business is characterized by seasonal fluctuations, dependence on external factors, and, hence, persistent risks in management, cyclical development of socioeconomic system, a variable ratio of uncontrolled and controlled processes, changing human needs and interests. The management of most of these companies decided to implement crisis measures (to a greater or lesser extent). An assessment of the current state of company management was carried out on the basis of a qualimetric approach using expert assessment methods. Example on KSG Agro is given in Figure 8.

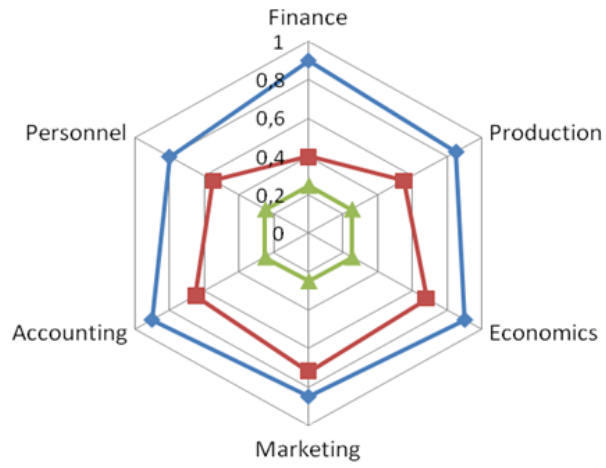

Sufficient level $\rightarrow$-Range of valid values $\rightarrow$ Critical area

Figure 8. The results obtained from the assessment of the current state of activity management for KSG Agro*

*Source: own development of the authors.

Qualimetric section of the results obtained from diagnostics of management systems (Fig. 8), where the outer contour describes the ideal level of evaluation of the performed management functions; the internal one stands for critical level; and the middle zone shows the level of admissible values of estimates. Next, respondents were asked to answer the following questions: 1) Does the company implement crisis measures? 2) What is the attitude of the employees towards crisis measures? 3) What is the reason for displaying resistance to crisis measures? When analysing the answers, the following results were obtained: $65 \%$ of respondents confirmed the implementation of crisis measures in a planned manner; $28 \%$ gave a negative answer; $7 \%$ showed reluctance to answer the questionnaire and 
remained neutral. When analysing the answers to the questions on the attitude of company employees towards crisis measures, $49 \%$ of respondents indicated passive perception (quasi-functional attitude), $27 \%$ displayed readiness for crisis measures (functional attitude), $18 \%$ demonstrated passive resistance to crisis measures (dysfunctional attitude) and $6 \%$ could not decide on the answer.

A deeper analysis of the age factor influencing the attitude of company employees towards crisis measures revealed the following results (Table 2).

Table 2. Distribution of the attitude shown by the employees towards crisis measures with respect to age groups*

\begin{tabular}{|c|c|c|c|c|c|}
\hline \multirow{2}{*}{$\begin{array}{c}\text { The attitude shown by employees towards crisis } \\
\text { measures }\end{array}$} & \multirow{2}{*}{$\begin{array}{c}\text { As a } \\
\text { percentage, } \%\end{array}$} & \multicolumn{4}{|c|}{ Interval groups by age, \% } \\
\hline & & Under 25 & $26-35$ & $36-50$ & Above 50 \\
\hline Quasi-functional attitude (passive perception) & 49 & 6 & 4 & 12 & 27 \\
\hline Functional attitude (readiness for crisis changes) & 27 & 13 & 8 & 5 & 1 \\
\hline Dysfunctional attitude (resistance to crisis changes) & 18 & 1 & 1 & 4 & 12 \\
\hline Respondents who could not make clear choices & 6 & 1 & 0.5 & 1.5 & 3 \\
\hline Total & 100 & 13.5 & 22.5 & 43 & 21 \\
\hline
\end{tabular}

*Source: own development of the authors.

Passive perception of crisis measures was shown by $49 \%$ of respondents among which $27 \%$ of employees were over the age of 50 and $12 \%$ of respondents were aged 36-50. Functional attitude was typical for $27 \%$ of respondents, with $13 \%$ of employees under the age of 25 and $8 \%$ of respondents aged 26-35. At the same time, the level of their professional training is important (skilled workers more easily perceive the long-term goals and opportunities that open up during the implementation of crisis measures). Dysfunctional attitude was shown by $18 \%$ of respondents with $12 \%$ over 50 . Out of $6 \%$ of respondents, $3 \%$ of employees over the age of 50 and $1 \%$ of people under the age of 25 could not decide on the answer. Most often they include young people with uncertain prospects for further work and professional growth.

Next, the reasons for displaying resistance to management innovations in the field of crisis management were analysed. The main ones turned out to be as follows: low awareness (25\%), conservative views $(23 \%)$, uncertainty of prospects for further work and professional growth (18\%), fear of maintaining the efficiency of their work $(21 \%)$, lack of help from management $(5 \%)$, others $(8 \%)$. At the same time, the main reasons for the quasi-functional attitude towards crisis management innovations are the uncertainty of prospects for further work and professional growth (48\%) and low awareness (35\%).

The main reasons for the dysfunctional attitude towards crisis innovations are the fear of maintaining the efficiency of their work (52\%) and conservative views $(14 \%)$.

In general, the results show that companies do not have a high degree of readiness for change that causes crisis management measures, and the susceptibility to managerial innovation is at a medium level.

In times of crisis, it becomes necessary to implement or revise corporate accounting standards, reporting systems, principles and rules for displaying information.

The process of labour activity management is an element of the company's overall strategy and is necessary in order to implement adoption of crisis management decisions by decreasing the personnel's resistance to change.

From the point of view of the human factor, the crisis situation is characterized by the emergence of at least two problems: inconsistency between the professional tools used by the company staff and necessary for the new situation and the inadequacy of norms and rules for internal organizational environment (actually corporate or organizational culture) under new conditions.

Thus, we can assume that from the point of view of the human component, the crisis situation is determined externally by the need to change the type of professional activity, and internally - by the organizational culture.

Table 3 shows innovative accounting and financial technologies that ensure the process of successfully implementing crisis management in companies. 
Table 3. Innovative accounting and financial technologies that ensure the implementation of the crisis management function*

\begin{tabular}{|c|c|c|}
\hline $\begin{array}{c}\text { Functions of crisis } \\
\text { management }\end{array}$ & Innovative accounting technologies & Innovative financial technologies \\
\hline Analysis & \multirow{2}{*}{$\begin{array}{c}\text { Methods of collecting, grouping, systematization of } \\
\text { primary information, reporting system }\end{array}$} & $\begin{array}{c}\text { Monitoring for "weak signals", } \\
\text { analysis of financial condition, analysis } \\
\text { of cash flows }\end{array}$ \\
\hline Planning & & $\begin{array}{c}\text { Budgeting (consolidated and } \\
\text { operational budgets), technologies to } \\
\text { increase financial stability }\end{array}$ \\
\hline Accounting & $\begin{array}{c}\text { Accounting units of the reserve system: accounts and } \\
\text { sub-accounts, analytical accounts, cost accounting, } \\
\text { costing, ABC analysis of suppliers and buyers, } A B C \\
\text { costing, value chain analysis, }\end{array}$ & \\
\hline Control & Internal reporting system & Plan-fact analysis of budgets \\
\hline Organization & Changes in the accounting policy of the enterprise & Observance of financial discipline \\
\hline
\end{tabular}

*Source: own development of the authors.

In order to effectively apply the selected innovative accounting and financial technologies, managers are to increase the competence of professionals (accountants and financial managers), strengthen their role and significance in the crisis group.

At the same time, managers develop a unified attitude among the company's employees towards the implementation of tasks related to the perception of crisis management as an important condition for ensuring the business activities and further development of the company. In order to solve the problem, the actions of management are aimed at forming crisis strategic thinking in their employees. Based on the results obtained from statistical observations and data processing, a number of methods were proposed and used for the company employees to overcome resistance and support crisis innovations in management (Table 4).

Table 4. Methods used to overcome resistance to change as a reaction of the company's crisis management system*

\begin{tabular}{|l|l|l|}
\hline \multicolumn{1}{|c|}{ Approach } & \multicolumn{1}{|c|}{ Advantages } & \multicolumn{1}{c|}{ Disadvantages } \\
\hline $\begin{array}{l}\text { Information and } \\
\text { communication }\end{array}$ & $\begin{array}{l}\text { provided that employees can be persuaded, they will assist in } \\
\text { making changes }\end{array}$ & $\begin{array}{l}\text { can be time consuming if used for } \\
\text { a significant number of employees }\end{array}$ \\
\hline $\begin{array}{l}\text { Assistance and } \\
\text { support }\end{array}$ & $\begin{array}{l}\text { effective method in case of overcoming the fear of employees } \\
\text { due to possible problems of adaptation to new conditions }\end{array}$ & $\begin{array}{l}\text { time consuming, may become too } \\
\text { expensive to use }\end{array}$ \\
\hline $\begin{array}{l}\text { Participation } \\
\text { and interest }\end{array}$ & participants will feel responsible for making change & $\begin{array}{l}\text { time consuming, may be } \\
\text { ineffective }\end{array}$ \\
\hline
\end{tabular}

*Source: own development of the authors.

When selecting them, we relied on the research conducted by Gordon G. et al. [22], Riley J. B. [23] who studied the employees' perception of managerial behaviour that could build trust in the follower and leader. The use of methods was limited in time (the study was conducted in January-June, 2020). The results on reducing resistance to innovative management change in companies that were part of the study are presented in Table 5 .

Table 5. Distribution of the attitude towards crisis change (by the age groups) after carrying out measures to overcome resistance in employees*

\begin{tabular}{|l|c|c|c|c|c|}
\hline \multirow{2}{*}{$\begin{array}{c}\text { The attitude of employees to crisis change in their } \\
\text { company }\end{array}$} & $\begin{array}{c}\text { As a } \\
\text { percentage, } \\
\%\end{array}$ & \multicolumn{3}{|c|}{ Interval groups by age, $\%$} \\
\cline { 3 - 6 } & Under 25 & $26-35$ & $36-50$ & Above 50 \\
\hline Quasi-functional attitude (passive perception) & 43 & 5 & 4 & 10 & 24 \\
\hline Functional attitude (readiness for crisis changes) & 39 & 18 & 12 & 6 & 3 \\
\hline Dysfunctional attitude (resistance to crisis changes) & 14 & 1 & 1 & 3 & 9 \\
\hline Respondents who could not make clear choices & 4 & & & 2 & 2 \\
\hline Total & 100 & 24 & 17 & 21 & 38 \\
\hline
\end{tabular}

*Source: own development of the authors. 
Thus, the quasi-functional attitude was reduced by $6 \%$ in general, the dysfunctional one - by $4 \%$. Respondents who were able to determine the attitude towards innovative management change in the company accounted for $2 \%$ more compared to the percentage obtained before the introduction of methods used to overcome resistance. The ability to influence the factors of resistance is of great significance for the successful implementation and crisis management in the company. An important condition for overcoming resistance in staff is the participation of employees in changes occurring within the company, as well as the role of formal and informal leaders in ensuring the effectiveness of organizational change processes. These conclusions are consistent with researches that argue that adaptation is associated with change in the management system of the company and it should consider a number of components, including responsibility for decision-making and counteracting the opportunistic behaviour of employees through change; or with researches on the use of mild procedures when implementing the training system in order to improve the performance of the company's staff [23].

\section{Conclusion}

This study presents a convenient methodology for crisis management based on innovative accounting and financial technologies. The power and efficiency of crisis management is determined by its compliance with the current management system of the company. Practical experience in implementing managerial innovations shows the lack of systematic and purposeful measures to deal with resistance to change in the personnel. The introduction of crisis measures inevitably entails changes in the company's management system. The use of innovative accounting and financial technologies to ensure the process of crisis management within companies has demonstrated not only their effectiveness, but also the need for organizational change and overcoming resistance to such change. Organizational change is characterized by significant inertia, which makes it impossible to quickly adapt to any change in the management system. Therefore, we suggest considering the possibility of implementing accounting and financial technologies with the simultaneous expansion of competencies in financial and accounting employees which make up the crisis group. This will help reduce resistance to change among accounting and financial staff when implementing the mechanism of crisis management within companies.

\section{Recommendations}

One of the most crucial issues is to build and improve the management system of the company, which counteracts crisis situations. With all the variety of approaches to solving this problem, it is impossible to identify universal accounting and financial technologies to ensure it since each organization has individual characteristics. However, their use significantly increases the effectiveness of crisis measures, as it will reduce the probability of crises and decrease the amount of possible damage based on the information platform formed by equal degree of aggregation and containing data on the basic parameters of external and internal environment.

\section{References}

[1]. Dobrowolski, Z. (2020). After COVID-19. Reorientation of crisis management in crisis. Entrepreneurship and Sustainability Issues, 8(2), 799-810. doi:10.9770/jesi.2020.8.2(48)

[2]. Iershova N, T. M., Garkusha, V., \& Miroshnik O, N. K. L. (2019). Economic security of the enterprise: scientific and practical aspects of accounting and analytical support. Financial and credit activities: problems of theory and practice, (2), 29.

[3]. Horvathova, J., \& Mokrisova, M. (2020). Business competitiveness, its financial and economic parameters. Montenegrin Journal of Economics, 16(1), 139-153.

[4]. Handayani, B. D., Rohman, A., Chariri, A., \& Pamungkas, I. D. (2020). Corporate Financial Performance on Corporate Governance Mechanism and Corporate Value: Evidence from Indonesia. Montenegrin Journal of Economics, 16(3), 161-171. doi:10.14254/1800-5845/2020.16-3.13

[5]. Wyrwa, J. (2020). A review of the European Union financial instruments supporting the innovative activity of enterprises in the context of Industry 4.0 in the years 2021-2027. Entrepreneurship and Sustainability Issues, 8(1), 1146-1161.

[6]. Liubov, S., Tetiana, K., Maryna, S., Yuliia, S., \& Iurii, G. (2018). Raw-Materials Potential of Corporate Enterprises: Topical Issues of Accounting, Analytical Procurement and Financial Backing. Academy of Accounting and Financial Studies Journal, 22(3), 1-7.

[7]. Bondar, M., Iershova, N., Tkachenko, M., Garkusha, V., \& Yavorsky, S. (2020). Financial Decisions Taking Into Account Management Reporting Of Enterpise. Financial and credit activity: problems of theory and practice, 2(33), 84-92.

[8]. Hughes, M. (2011). Do 70 per cent of all organizational change initiatives really fail?. Journal of Change Management, 11(4), 451-464. doi.org/10.1080/14697017.2011.630506 
[9]. Goffin, K., Åhlström, P., Bianchi, M., \& Richtnér, A. (2019). Perspective: State-of-the-art: The quality of case study research in innovation management. Journal of Product Innovation Management, 36(5), 586-615.

[10]. Thomsen, S. (2004). Corporate values and corporate governance. Corporate Governance-The International Journal of Effective Board Performance, 4(4), 29-46.

[11]. Atamas, P., Serbov, M., Omelyanenko, V., Kravchenko, I., \& Portna O. (2019). Sustainable Development in the Regions on the Basis of the Stakeholder Concept. Proceedings of the 34th International Business Information Management Association Conference, IBIMA 2019: Vision 2025: Education Excellence and Management of Innovations through Sustainable Economic Competitive Advantage. 9503-9510.

[12]. Renkema, M., Meijerink, J., \& Bondarouk, T. (2016). Advancing multilevel thinking in human resource management research: Applications and guidelines. Human resource management review, 27(3), 397-415. doi:10.1016/j.hrmr.2017.03.001

[13]. Heyden, M. L., Fourné, S. P., Koene, B. A., Werkman, R., \& Ansari, S. (2017). Rethinking 'topdown'and 'bottom-up'roles of top and middle managers in organizational change: Implications for employee support. Journal of management studies, 54(7), 961-985. doi:10.1111/joms.12258

[14]. Ijaz, S., \& Vitalis, A. (2011). Resistance to organizational change: putting the jigsaw together. International review of business research papers, 7(3), 112-121.

[15]. Gruman, J. A., \& Saks, A. M. (2011). Performance management and employee engagement. Human resource management review, 21(2), 123-136. doi:10.1016/j.hrmr.2010.09.004
[16]. Kożuch, A. J. (2020). Dysfunctions of the process of managing finance in Polish communes-the perspective of management sciences. Entrepreneurship and Sustainability Issues, 8(1), 442-453. doi:10.9770/jesi.2020.8.1(31)

[17]. Bawaneh, S. S. (2019). Using the Balanced Scorecard Perspectives to Measure the Performance of Manufacturing Companies in Jordan. Academy of Accounting and Financial Studies Journal, 23(5), 115.

[18]. Koev, S. R., Pavliuk, S., Derhaliuk, M., Sokolova, L., \& Portna, O. (2020). Resource Strategy for Enterprise Management as a Tool to Ensure Its Competitiveness. Academy of Strategic Management Journal, 19(4), 1-8.

[19]. Huang, S. Y., Chiu, A. A., Chao, P. C., \& Wang, N. (2019). The Application of Material Flow Cost Accounting in Waste Reduction. Sustainability, 11(5), 1-27. doi:10.3390/su11051270

[20]. Van der Wal, Z., \& Huberts, L. (2008). Value solidity in government and business: Results of an empirical study on public and private sector organizational values. The American Review of Public Administration, 38(3), 264-285. doi:10.1177/0275074007309154

[21]. Shi-Rui, S., \& Gale, A. (2008). Investigating project managers' work values by repertory grids interviews. The Journal of Management Development, $27(6), 541$. doi:10.1108/02621710810877811

[22]. Gordon, G., Gilley, A., Avery, S., Gilley, J. W., \& Barber, A. (2014). Employee perceptions of the manager behaviors that create follower-leader trust. Management and Organizational Studies, 1(2), 44-58. doi:10.5430/mos.v1n2p44

[23]. Rieley, J. B. (2016). What to do when employees are gaming the system: Overcoming resistance to change. Global Business and Organizational Excellence, 35(2), 31-37. doi:10.1002/joe.21653 